\title{
Effect of drip and surface irrigation on yield, water- use-efficiency and economics of capsicum (capsicum annum 1.) Grown under mulch and non mulch conditions in eastern coastal india
}

By

J.C. Paul ${ }^{1}$, J.N. Mishra ${ }^{2}$, P.L. Pradhan ${ }^{3}$, B. Panigrahi ${ }^{4}$

\begin{abstract}
A field experiments was conducted on the loamy sand soil at Bhubaneswar in eastern coastal of India for two years (2007-08 and 2008-09) to evaluate the yield, water-useefficiency and economic feasibility of capsicum grown under drip and surface irrigation with non-mulch and black Linear Low Density Poly Ethylene (LLDPE) plastic mulch. Actual evapotranspiration for capsicum crop was estimated using modified pan evaporation method. The net irrigation volume (V) was determined after deducting the effective rainfall. Effect of three irrigation levels viz. VD, $0.8 \mathrm{VD}$ and $0.6 \mathrm{VD}$ (VD = full irrigation volume with drip) in conjunction with LLDPE mulch and no mulch were studied on biometric and yield response of capsicum crop. The results of surface irrigation were compared with drip irrigation system under no mulch and in conjunction with LLDPE mulch. The study indicated better plant growth, more number of fruits per plant and enhancement in the yield under drip irrigation system with LLDPE mulch. The highest yield $(28.7 \mathrm{t} / \mathrm{ha})$ was recorded under 100\% net irrigation volume with drip irrigation (VD) and plastic mulching as compared to other treatments. This system increased the yield and net seasonal income by $57 \%$ and $54 \%$ respectively as compared to conventional surface irrigation without mulch with a benefit cost ratio of 2.01 . The benefit cost ratio was found to be the highest (2.44) for the treatment VD without mulch. Drip irrigation system could increase the yield by $28 \%$ over surface irrigation even in the absence of mulch. Similarly, LLDPE mulch alone could increase the yield by $13 \%$ even in the absence of drip irrigation system.
\end{abstract}

Key Words: surface irrigation, capsicum annum, vegetable, crop

\section{Introduction}

Presently in India 7.49 million ha area is cultivated with vegetable with an annual production of 116.03 million tonnes. It is estimated that, by 2020 the vegetable demand of the country would be around 135 million tonnes. To achieve

1,2,3 Associate Professor, College of Agricultural Engineering and Technology, Orissa University of Agriculture and Technology, Bhubaneswar, India.

${ }^{4}$ Professor, College of Agricultural Engineering and Technology, Orissa University of Agriculture and Technology, Bhubaneswar, India. 
this target, attention must be focused on the vertical expansion, strengthened with the boon of the technology instead of horizontal expansion just by increasing the crop area (Rai and Pandey, 2008). The working group on horticulture constituted by the Planning Commission has recommended the deployment of hi-tech horticulture and precision farming for achieving vertical growth in horticulture. Hi-tech interventions in horticultural crops proposed by National Committee on Plasticulture Applications in Horticulture (NCPAH), Govt. of India include drip irrigation and greenhouse technology and the crops selected are capsicum, chilli, tomato and flowers like rose, carnation and gerbera (Samuel and Singh, 2004). Drip irrigation with its ability to small and frequent applications of water has created interest among the farmers because of less water requirement, increased production and better quality produce. Economic evaluation of drip irrigation in fruit crops (coconut, mango and sapota) in Orissa reveales that, this system conserves considerable amount of water and results better returns despite higher initial investment (Behera and Sahoo, 1998). The response of tomato and okra to drip irrigation in terms of yield improvement is found to be different in different agro-climatic and soil conditions in India (Shrivastava et al, 1994; Tiwari et al, 1998a; 1998b; Horo et al, 2003; Singh, 2007; Vankar and Shinde, 2007). Use of soil cover and mulching is also known to be beneficial chiefly through their influence on soil moisture conservation, solarization and control of weeds. Beneficial response of plants to mulch includes early production, more yield and reduced insect and disease problems (Tiwari et al, 1998a; Pattanaik et al, 2003). Linear Low Density Poly Ethylene (LLDPE) plastic films have been proved as better mulch because of their puncture resistance quality, thinness and lower cost (Panda, 2004).

Capsicum (Capsicum annum L.) or bell pepper is an important cool season vegetable crop of India. It is richer in vitamins than tomato, especially in A and C. In India, it is grown mainly during the cooler parts of the year (autumn-winter) when the temperature is low (Singh et al., 1993). The production of this crop is affected adversely by moisture deficit. Productivity of the crop can be increased by adopting improved package of practices, particularly in-situ moisture conservation by mulching as well as high-tech irrigation especially drip irrigation with appropriate irrigation scheduling. Numerous experiments have reported the benefits of black LLDPE mulch in several crops, but research is limited on response of capsicum production by this method. Keeping this in background, the present study was undertaken to study the effect of drip irrigation system and plastic mulch on capsicum crop and compare the result with the conventional method of growing the crop under surface irrigation without mulch. 


\section{Materials and methods}

A field experiment was conducted at Precision Farming Development Centre experimental site located at Orissa University of Agriculture and Technology, Bhubaneswar, India. The soil of the area is loamy sand and acidic in nature having $\mathrm{p}^{\mathrm{H}}$ of 6.2. Capsicum seedlings (variety California Wonder) of 25 days were planted with a spacing of $60 \mathrm{~cm}$ x $45 \mathrm{~cm}$ during $1^{\text {st }}$ week of November during the year 2007 and 2008. The experiment was laid out in randomized block design having eight treatments replicated thrice with a plot size of $4.5 \mathrm{~m} \times 1.2 \mathrm{~m}$. One metre gap was provided between each plot to avoid effect of irrigation treatment. The treatment details are as follows:

$\mathrm{T}_{1}=100 \%$ irrigation requirement through drip irrigation (VD)

$\mathrm{T}_{2}=80 \%$ irrigation requirement through drip irrigation $(0.8 \mathrm{VD})$

$\mathrm{T}_{3}=60 \%$ irrigation requirement through drip irrigation (0.6VD)

$\mathrm{T}_{4}=100 \%$ irrigation requirement by surface irrigation $(\mathrm{V})$

$\mathrm{T}_{5}=100 \%$ irrigation requirement through drip irrigation with black LLDPE mulch $(\mathrm{VD}+\mathrm{M})$

$\mathrm{T}_{6}=80 \%$ irrigation requirement through drip irrigation with black LLDPE mulch $(0.8 \mathrm{VD}+\mathrm{M})$

$\mathrm{T}_{7}=60 \%$ irrigation requirement through drip irrigation with black LLDPE mulch $(0.6 \mathrm{VD}+\mathrm{M})$

$\mathrm{T}_{8}=100 \%$ irrigation requirement by surface irrigation with black LLDPE mulch $(\mathrm{V}+\mathrm{M})$

The cultural practices of the crop were followed as per the recommendations by Indian Council of Agricultural Research, New Delhi (Thamburaj and Singh, 2003). The LLDPE film of 50-micron thickness was used for mulching around the plant. The lateral lines of $12 \mathrm{~mm}$ diameter LLDPE pipes were laid along the crop rows and each lateral served two rows of crop. The laterals were provided with on line turbokey dripper of $4 \mathrm{lit} / \mathrm{hr}$ discharge capacity. LLDPE pipes of $75 \mathrm{~mm}$ diameter were used for main and $63 \mathrm{~mm}$ diameter was used for sub-main. The main line was directly connected to a $1.5 \mathrm{hp}$ pump installed to lift water from an open sump. The manifold unit was connected with a screen filter, a pressure gauge and control valve. The duration of delivery of water to each treatment was controlled with the help of gate valves provided at the inlet end of each lateral. In case of surface irrigation, irrigation was scheduled at weekly interval (Fig. 1). 


\section{Estimation of irrigation water requirement}

The water requirement of the crop was computed on daily basis by using the following equation as suggested by Shukla et al., (2001).

Where,

$$
\mathrm{V}=\mathrm{E}_{\mathrm{p}} \cdot \mathrm{K}_{\mathrm{p}} \cdot \mathrm{K}_{\mathrm{c}} \cdot \mathrm{S}_{\mathrm{p}} \cdot \mathrm{S}_{\mathrm{r}} \cdot \mathrm{W}_{\mathrm{p}}
$$

$\mathrm{V}=$ Volume of water required (litre / day / plant)

$\mathrm{E}_{\mathrm{p}}=$ Pan evaporation as measured by Class-A pan evaporimeter ( $\mathrm{mm} /$ day)

$\mathrm{K}_{\mathrm{c}}=$ Crop co-efficient (co-efficient depends on crop growth stage)

$\mathrm{K}_{\mathrm{p}}=$ Pan co-efficient

$\mathrm{S}_{\mathrm{p}}=$ Plant to plant spacing $(\mathrm{m})$

$\mathrm{S}_{\mathrm{r}}=$ Row to row spacing $(\mathrm{m})$

$\mathrm{W}_{\mathrm{p}}=$ Fractional wetted area, which varies with different growth stage $(0.3$ to 1.0$)$

The values of pan coefficient and crop coefficients were taken from (Doorenbos and Pruitt, 1977). The water requirement of capsicum crop was estimated on daily basis for all months considered under study. Daily time to operate drip irrigation system was worked out taking the application rate per plant. Drip system was scheduled on alternate days; hence total quantity of water delivered was cumulative water requirement of two days.

Observations on water requirement, growth character and yield of capsicum were recorded and analyzed statistically following the standard procedures (Panse and Sukhatme, 1985). The water use efficiency (WUE) of the crop was determined by dividing the yield with water requirement of the crop.

\section{Economic analysis}

Benefit-Cost ratio and net profit were carried out to determine the economic feasibility of the crop using surface and drip irrigation as suggested by Tiwari et al. (1998a). The seasonal system cost of drip irrigation system included depreciation, prevailing bank interest rate, and repair and maintenance cost of the system. The fixed cost of drip irrigation system was determined to be Rs $110000 /$ ha. The useful life of drip system was considered to be 10 years. The system cost was evaluated by distributing the fixed cost of system over life period of drip irrigation set. For calculating depreciation, the life of the drip irrigation set and $10 \%$ junk value was considered. The interest was calculated on the average of investment of the drip irrigation set taking into consideration the value of the set in the first and last year@10\% per annum. Cost of repairs and maintenance of set is@2\% of initial cost of the drip irrigation set per year. The cost of cultivation includes expenses incurred in land preparation, interculture operation, 
fertilizer, crop protection measures, irrigation water and harvesting with labour charges. Therefore, total seasonal cost was worked as: depreciation, interest, repairs and maintenance cost of set + cost of cultivation + cost of mulch. The income from produce was calculated using prevailing average market price of capsicum@Rs1000/ q.

\section{Results and discussion}

\subsection{Growth and yield attributes}

Two years pooled data of biometric parameters like plant height, number of leaves per plant and average yield attributing characters such as days taken to flowering, average single fruit weight, number of fruits per plant and the yield of capsicum are presented in Table 1. The results revealed that, these characters and yield are significantly superior in the treatment $T_{5}(100 \%$ irrigation requirement through drip irrigation with LLDPE mulch) as compared to the rest of the treatments. The height of plant under treatment $\mathrm{T}_{5}(78.6 \mathrm{~cm})$ was found to be significantly highest among all other treatments and is $55 \%$ higher than the height of plant under surface irrigation without mulch $\left(\mathrm{T}_{4}\right)$. As regards to number of leaves per plant, maximum value was recorded in treatment $T_{5}(99.7)$ followed by treatment $\mathrm{T}_{6}(97.3)$ and the lowest value was in treatment $\mathrm{T}_{4}$ (76.7).

All the yield attributing characters are found to be significantly higher in treatment $\mathrm{T}_{5}$ than other treatments. The treatment $\mathrm{T}_{5}$ recorded $36 \%, 43 \%$ and 23 $\%$ higher number of fruits per plant, single fruit weight and days to flowering respectively than control $\left(\mathrm{T}_{4}\right)$. Mulch was observed to have significant effect on yield attributing characters than non-mulch treatments.

The highest increase in vegetative growth in treatment $T_{5}$ might be due to the availability of soil moisture as well as temperature at optimum level (Tiwari et al, 1998a; Tiwari et al, 1998b; Pattanaik et al., 2003). The lowest value of vegetative growth in $\mathrm{T}_{4}$ might be because of unfavourable moisture regime (moisture stress or excess moisture) in the soil through surface irrigation and competition of weeds for nutrients (Pattanaik et al., 2003; Agrawal and Agrawal, 2005). The increased growth attributes might have supplied water and nutrients in adequate proportion, which resulted in triggering the production of plant growth hormone, viz. indole acetic acid (IAA) and higher number of leaves throughout the cropping period (Sankar et al., 2008).

\subsection{Crop yield}

The drip irrigation in combination with mulch significantly increased the yield of capsicum as compared to drip irrigation without mulch (Table 1). Among various treatments, the highest yield $(28.7 \mathrm{t} / \mathrm{ha})$ was recorded under treatment $\mathrm{T}_{5}$, which increased by $57 \%$ over surface irrigation. Drip irrigation with LLDPE mulch treatments $\left(T_{5}, T_{6}\right.$ and $\left.T_{7}\right)$ increased the percentage in yield by $15 \%, 14 \%$ 
and $16 \%$ respectively as compared to drip irrigation without mulch treatments $\left(\mathrm{T}_{1}, \mathrm{~T}_{2}\right.$ and $\left.\mathrm{T}_{3}\right)$. The low yield was recorded under surface irrigation method (18.2 $\mathrm{t} / \mathrm{ha}$ ). This might be due to water stress during the critical growth period, coupled with aeration problem in first few days immediately after irrigation. Another reason to get low yield by surface irrigation might be due to less availability of nutrients for crop growth due to leaching with high weed infestation between the crops (Pattanaik et al., 2003). This result corroborated the findings of Tiwari et al. (1998a); Tiwari et al. (1998b) and Singh (2007). In drip irrigation system, water is applied at a low rate for a longer period at frequent intervals near the plant root zone through lower pressure delivery system, which increases the availability of nutrients near the root zone with a reduction in leaching losses. More nutrient availability, especially near the root zone might have increased the translocation of photosynthetes to storage organ of capsicum resulting in an increased weight of capsicum (Sankar et al., 2008). Based on the results, drip irrigation treatments $\left(T_{1}\right.$, $\mathrm{T}_{2}$ and $\mathrm{T}_{3}$ ) increased yield by $38 \%, 30 \%$ and $8 \%$ higher respectively as compared to surface irrigation $\left(\mathrm{T}_{4}\right)$. Therefore the study revealed that, even if $40 \%$ less quantity of water was supplied through drip irrigation $\left(\mathrm{T}_{3}\right), 8 \%$ higher yield of capsicum was established as compared to surface irrigation. This result is in close agreement with the findings of Tiwari et al. (1998a). The beneficial effect of yield characters advantage vis-à-vis better water-use-efficiency through drip irrigation is attributed to the continuous supply of water in required quantity at right time without flooding to cause hypoxia. Therefore, the roots remain well aerated (Lingaiah et al, 2005). Mulch alone in surface irrigation method $\left(\mathrm{T}_{8}\right)$ could increase yield upto $13 \%$ than without mulch treatment $\left(\mathrm{T}_{4}\right)$. The beneficial effect of black LLDPE mulch in tomato and okra was also reported earlier by Shrivastava et al. (1994); Tiwari et al. (1998a); Tiwari et al. (1998b); Horo et al. (2003); Singh (2007); Vankar and Shinde (2007).

The water requirement for $100 \%$ net irrigation volume under drip irrigation system for capsicum was $319 \mathrm{~mm}$. The highest yield was obtained under treatment $T_{5}$ with the same quantity of water requirement $(319 \mathrm{~mm})$. Thus it can be concluded that drip irrigation gave highest yield with the same quantity of 319 $\mathrm{mm}$ of water as compared to surface irrigation and drip irrigation system with LLDPE plastic mulch increased yield by $57 \%$ over surface irrigation with same quantity of irrigation water. Similar results have been obtained by Tiwari et al. (1998a) for okra crop at Kharagpur, West Bengal.

\subsection{Water use efficiency}

Water use efficiency (yield per unit area per unit depth of water used) decreased with increase in irrigation levels i.e. 0.6 VD, 0.8 VD and VD for all the treatments of drip irrigation system. There was significant effect of LLDPE mulch over drip irrigation system alone. The increase in water use efficiency for drip 
irrigation system alone $\left(\mathrm{T}_{1}\right)$ and drip irrigation system with LLDPE mulch $\left(\mathrm{T}_{5}\right)$ over conventional surface irrigation $\left(\mathrm{T}_{4}\right)$ was $38 \%$ and $57 \%$ respectively. Similar trend has been reported in water use efficiency for okra crop by Tiwari et al. (1998a); for tomato crop by Tiwari et al. (1998b) and Singh (2007).

\subsection{Economic feasibility}

Maximum net profit of Rs 191600/ha with B: C ratio of 2.01 was recorded in treatment $T_{5}$ and lowest net profit of Rs 132600/ha with a B: C ratio of 1.39 in $\mathrm{T}_{7}$ (Table 2). It is observed that, the mulched treatments $\mathrm{T}_{5}, \mathrm{~T}_{6}$ and $\mathrm{T}_{7}$ gave better net return per ha than their corresponding treatments without mulching. But higher B: C ratios were recorded in treatments without mulch than their corresponding treatments of LLDPE mulch. The results are in conformity with the findings of Singh (2007). The B: C ratio was 2.1 in conventional irrigation method $\left(\mathrm{T}_{4}\right)$ due to comparatively lower system cost and no mulch was used. However, the net profit in drip irrigated treatments with mulch was observed to be maximum (Rs 191600) in treatment $T_{5}$ followed by $T_{1}$ (Rs 178100), $T_{6}$ (Rs 173600), $T_{2}$ (163100), $T_{7}$ (132600) and $T_{3}$ (123100). The net profit per $\mathrm{mm}$ of water used (Rs 670.2/ha) was maximum in case of $\mathrm{T}_{6}$, where the water used was also less $(259 \mathrm{~mm})$. High net return of Rs 178100 / ha was obtained in drip irrigated treatments without mulch $\left(T_{1}\right)$ which is Rs 53500 / ha (43\%) higher than control $\left(\mathrm{T}_{4}\right)$, proving the beneficial effect of drip irrigation system. Similar trends have been reported in net profit, B.C. ratio and net profit per $\mathrm{mm}$ of water used for okra by Tiwari et al. (1998a) and for tomato crop by Tiwari et al. (1998b) and Singh (2007).

\section{Conclusion}

The drip irrigation system is observed to be economical and cost effective as compared with conventional surface irrigation. As a result, the use of drip irrigation system either alone or in combination with mulching, could increase the capsicum yield up to an extent of $57 \%$ over surface irrigation method with the same quantity of water. It was also observed that, $319 \mathrm{~mm}$ of water would be sufficient to irrigate one hectare of capsicum crop with the drip irrigation system in the sub-humid agro-climatic conditions of Bhubaneswar. The net profit could be increased by $54 \%$ over the normal surface method by adopting drip irrigation system with mulch.

\section{References}

Agrawal N and Agrawal S. 2005. Effect of drip irrigation and mulches on the growth and yield of banana cv. Dwaraf Cavendish. Indian Journal of Horticulture, 62(3): 238-240.

Behera B P and Sahoo N. 1998. Economic evaluation of a drip irrigation system in Orissa. Environment and Ecology, 16(2): 297-299. 
Doorenbos J and Pruitt W O. 1977. Guidelines for predicting crop water requirements. Irrigation and Drainage Paper 24, FAO, Rome.

Horo P, Chowdhary B M, Prasad B N and Kandeyang S. 2003. Effect of micro irrigation on growth and yield of tomato in Jharkhand. The Orissa Journal of Horticulture, 31(2): 80-83.

Lingaiah D, Katti G S and Mohammad S. 2005. Influence of drip irrigation on crop growth, yield and water use efficiency in cabbage. International Journal of Agricultural Sciences, 1(1): 110-111.

Panda S C. 2004. Mulching. In: Panda S C, Patnaik K K, Mishra J N, Pradhan P C and Alim M A. (Eds.), Training Manual on Precision Farming in Horticulture. PFDC, OUAT, Bhubaneswar.

Panse V G and Sukhatme P V. 1985. Statistical Methods for Agricultural Workers. ICAR, New Delhi.

Pattanaik S K, Sahu N N, Pradhan P C and Mohanty M K. 2003. Response of Banana to drip irrigation under different irrigation designs. Journal of Agricultural Engineering, IS AE, 40(3):29-34.

Rai M and Pandey A K. 2008. Vegetable Sector: Growing with the nation. Agriculture Year Book 2008. Agriculture Today, New Delhi. pp: 66-72.

Samuel J C and Singh H P. 2004. Perspective of Hi-Tech Horticulture and Precision Farming. In: Panda S C, Patnaik K K, Mishra J N, Pradhan P C and Alim M A. (Eds.), Training Manual on Precision Farming in Horticulture. PFDC, OUAT, Bhubaneswar.

Sankar V, Lawande K E and Tripathy P C. 2008. Effect of micro irrigation on growth, yield and water-use-efficiency of onion (Allium Cepa) under western Maharashtra conditions. Indian Journal of Agricultural Sciences. 78(7): 584-588.

Shrivastava P K, Parikh M M, Sawali N G, and Raman S. 1994. Effect of drip irrigation and mulching on tomato yield. Agricultural Water Management, 25: 179-184.

Shukla K N, Singh P K and Singh K K. 2001. Crop Water Requirement under Drip Irrigation. Plasticulture Development Centre, GBPUAT, Pantnagar.

Singh D P, Anand N and Deshpande A A. 1993. Improvement of bell pepper. In: Chadha K L, Kallo G. (Eds.), Advances in Horticulture, vol. 5. Vegetable Crops. Part I. Malhotra Publishing House, New Delhi, pp 87-104.

Singh A. 2007. Economic feasibility of drip irrigated tomato crop under rainfed condition. Agricultural Engineering Today, IS AE, 31(3\&4): 1-5.

Thamburaj S and Singh N. 2003. Text book on Vegetables, Tuber crops and Spices. ICAR, New Delhi.

Tiwari K N, Mal P K, Singh R M and Chattopadhya A. 1998a. Response of Okra to drip irrigation under mulch and non-mulch conditions. Agricultural Water Management, 38: 91-102.

Tiwari K N, Singh, R M, Mal P K and Chattopadhya A. 1998b. Feasibility of drip irrigation under different soil covers in tomato. Journal of Agricultural Engineering, IS AE, 35(2): 41-49. 
Vankar R R and Shinde P P. 2007. Effect of micro-irrigation systems and polythene mulches on yield and yield attributes of tomato. The Orissa Journal of Horticulture, 35(1): 22-26.

Table 1 Growth, yield, water requirement and WUE of capsicum as influenced by different treatments (average data of two years)

\begin{tabular}{|l|l|l|l|l|l|l|l|l|}
\hline Treatments & $\begin{array}{l}\text { Plant } \\
\text { height, } \\
\mathrm{cm}\end{array}$ & $\begin{array}{l}\text { No. of } \\
\text { leaves } \\
\text { plant }\end{array}$ & $\begin{array}{l}\text { Days to } \\
\text { first } \\
\text { flowering }\end{array}$ & $\begin{array}{l}\text { Average } \\
\text { single } \\
\text { fruit wt., } \\
\mathrm{g}\end{array}$ & $\begin{array}{l}\text { No. of } \\
\text { fruits } \\
\text { per } \\
\text { plant }\end{array}$ & $\begin{array}{l}\text { Yield, } \\
\text { t/ha }\end{array}$ & $\begin{array}{l}\text { Water } \\
\text { requirement, } \\
\mathrm{mm}\end{array}$ & $\begin{array}{l}\text { Water use } \\
\text { efficiency, } \\
\text { kg/ha- } \\
\text { mm }\end{array}$ \\
\hline $\mathrm{T}_{1}$ & 66.6 & 95.9 & 62.2 & 98.1 & 8.8 & 25.1 & 319 & 78.6 \\
\hline $\mathrm{T}_{2}$ & 61.9 & 92.2 & 57.8 & 94.2 & 8.5 & 23.6 & 259 & 91.1 \\
\hline $\mathrm{T}_{3}$ & 53.9 & 84.4 & 53.6 & 88.3 & 8.1 & 19.6 & 199 & 98.4 \\
\hline $\mathrm{T}_{4}$ & 50.7 & 76.7 & 52.7 & 78.8 & 7.3 & 18.2 & 319 & 57.1 \\
\hline $\mathrm{T}_{5}$ & 78.6 & 99.7 & 64.7 & 112.7 & 9.9 & 28.7 & 319 & 89.9 \\
\hline $\mathrm{T}_{6}$ & 72.7 & 97.3 & 63.4 & 105.8 & 9.2 & 26.9 & 259 & 103.8 \\
\hline $\mathrm{T}_{7}$ & 60.7 & 93.7 & 56.7 & 92.1 & 8.4 & 22.8 & 199 & 114.5 \\
\hline $\mathrm{T}_{8}$ & 55.3 & 85.7 & 53.8 & 89.9 & 8.2 & 20.5 & 319 & 64.3 \\
\hline $\mathrm{SE}(\mathrm{m}) \pm$ & 1.02 & 0.72 & 0.21 & 0.86 & 0.09 & 0.42 & - & - \\
\hline $\mathrm{CD}(0.05)$ & 3.07 & 2.17 & 0.64 & 2.62 & 0.27 & 1.26 & - & - \\
\hline
\end{tabular}

Table 2 Economic analysis of various treatments for capsicum

\begin{tabular}{|c|c|c|c|c|c|c|c|c|c|}
\hline & omics & & & & Treat & ments & & & \\
\hline No & & $\mathrm{T}_{1}$ & $\mathrm{~T}_{2}$ & $\mathrm{~T}_{3}$ & $\mathrm{~T}_{4}$ & $\mathrm{~T}_{5}$ & $\mathrm{~T}_{6}$ & $\mathrm{~T}_{7}$ & $\mathrm{~T}_{8}$ \\
\hline 1 & Fixed cost, Rs/ha & 110000 & 110000 & 110000 & - & 110000 & 110000 & 110000 & - \\
\hline 2. & Seasonal system cost, Rs/ha & & & & & & & & \\
\hline & a. Depreciation & 9900 & 9900 & 9900 & - & 9900 & 9900 & 9900 & - \\
\hline & b. Inte & 00 & 5500 & 500 & - & 500 & 500 & 500 & - \\
\hline & c. Repair & 200 & 2200 & 2200 & 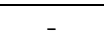 & 2200 & 2200 & 2200 & - \\
\hline & d. Total & 17600 & 17600 & 17600 & - & 17600 & 17600 & 17600 & - \\
\hline 3. & $\begin{array}{l}\text { Seasonal cost of cultivation, } \\
\text { Rs/ha }\end{array}$ & 55300 & 55300 & 55300 & 57400 & 55300 & 55300 & 55300 & 57400 \\
\hline 4. & Cost of mulch, Rs/ha & - & - & - & - & 2500 & 22500 & 22500 & 2500 \\
\hline 5. & $\begin{array}{l}\text { Seasonal total cost }(2 \mathrm{~d}+3+4), \\
\text { Rs } / \text { ha }\end{array}$ & 72900 & 72900 & 72900 & 57400 & 95400 & 95400 & 95400 & 79900 \\
\hline 6. & Water u & 319 & 259 & 199 & 319 & 319 & 259 & 199 & 319 \\
\hline 7. & Yield $\mathrm{c}$ & 25.1 & 23.6 & 19.6 & 18.2 & 28.7 & 26.9 & 22.8 & 20.5 \\
\hline 8. & Rs/ha & 251000 & 236000 & 196000 & 182000 & 287000 & 269000 & 228000 & 2050 \\
\hline 9. & Net profit (8-5), Rs & 178100 & 163100 & 123100 & 124600 & 191600 & 173600 & 132600 & 125100 \\
\hline 10. & Benefit & 2.44 & 2.23 & 1.69 & 2.1 & 2.01 & 1.82 & 1.39 & 1.57 \\
\hline 11. & $\begin{array}{l}\text { Net profit per hectare per } \mathrm{mm} \\
\text { of water used }(9 / 6) \text {, } \\
\text { Rs/mm/ha }\end{array}$ & 558.3 & \begin{tabular}{|l|}
629.7 \\
\end{tabular} & \begin{tabular}{|l|}
618.6 \\
\end{tabular} & 390.6 & 600.6 & 670.2 & 666.3 & 392.2 \\
\hline
\end{tabular}




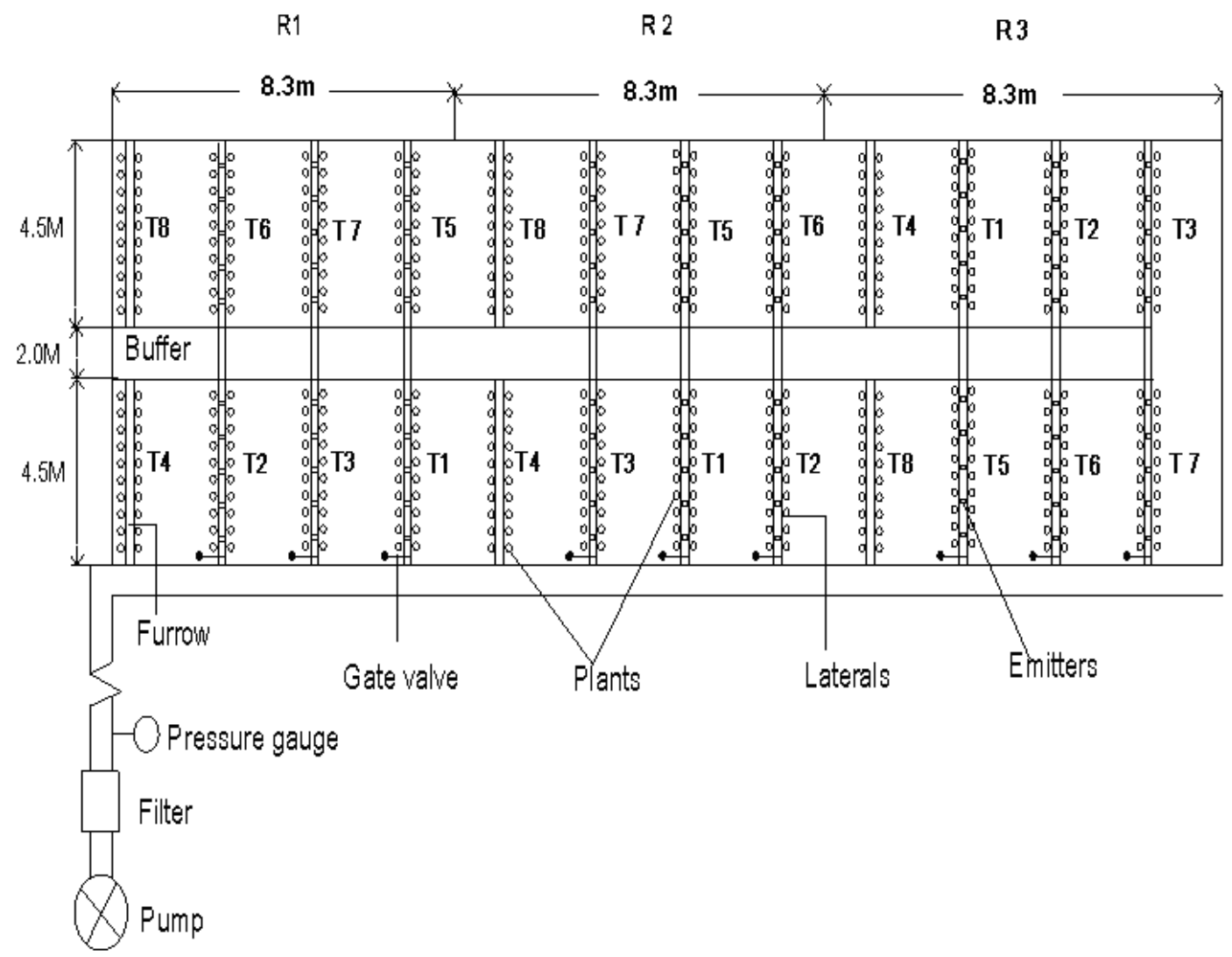

Fig.1: Drip irrigation layout for capsicum crop 